\title{
VLADIMÍR LEŠKO
}

(Koszyce)

\section{HEIDEGGER, BYCIE I CZAS A PROBLEM DZIEJÓW FILOZOFII (ALBO) HEIDEGGER A PROBLEM DZIEJÓW FILOZOFII}

Przez licznych filozofów, i to nie tylko heideggerystów, Bycie i czas Martina Heideggera wciąż uważane jest za jedną z najważniejszych prac dwudziestego wieku. Często w literaturze fachowej pomija się natomiast fakt, że jej autor już na początku lat czterdziestych ubiegłego wieku zajął wobec swego dzieła zdecydowanie krytyczne stanowisko, które może przypominać Wittgensteinowskie odrzucenie Traktatu logiczno-filozoficznego. Jednak, w odróżnieniu od Wittgensteina, podjął on próbę starannego ukrycia tego faktu przed fachową publicznością. Przedmiotem mojego studium jest przedstawienie ważnych powodów takiego właśnie postępowania Heideggera.

W Uwagach wstepnych do siódmego wydania Bycia $i$ czasu z 1953 roku, Martin Heidegger pisze, że wyrażenie „pierwsza część”, które pojawiało się we wszystkich poprzednich wydaniach, ostatecznie zostało porzucone. I zaraz potem dodaje, że po dwudziestu pięciu latach od ukazania się pierwszego wydania, bez ponownego opracowania części pierwszej, nie można dołączyć drugiej połowy. Heidegger ma na myśli próbę samokrytyki, która miałaby zarazem zabezpieczyć to, co możliwe jest jeszcze do uratowania. Tak zatem przedstawia się jedyna droga, której podjęcie - według Heideggera - jest konieczne, jeżeli kwestia bycia ma pozostać żywa $^{1}$. W 1942 roku, w liście do pisarza Maxa Kommerella, o wiele radykalniej ocenił swe dzieło: „Bycie $i$ czas było porażką” ${ }^{2}$. Z tym stwierdzeniem

\footnotetext{
$1 \mathrm{~W}$ polskim wydaniu Bycia $i$ czasu nie ma wspomianch przez autora Vorbemerkung (przyp. tłum). Por. M. Heidegger, Bytí a čas, prel. I. Chvatík, P. Kouba, M. Petříček jr. a J. Němec, Praha 2008, s. 7.

2 Cyt. za G. Figal, Úvod do Heideggera, prel. V. Zátka, Praha 2007, s. 48.
} 
należy się zdecydowanie zgodzić. Niemniej jednak potrzebna jest historyczno-filozoficzna analiza, by wykazać, w czym leży sedno porażki Heideggera, dlaczego to ambitne dążenie filozoficzne nie mogło skończyć się inaczej.

Heidegger jest zupełnie świadomy, że jego filozoficzne dzieło nie mogło zrealizować wyznaczonego przezeń celu, że musi on poszukiwać innego sposobu jego realizacji. Nadal otwarte pozostaje pytanie, w jaki sposób miałaby być na nowo opracowana pierwsza część Bycia $i$ czasu, a także jak można by dołączyć do niej drugą, zaplanowaną czesść ${ }^{3}$. Ale od razu w sposób nieunikniony powstałby nowy, poważny problem. Nawet jeżeli Heideggerowi udałoby się ponownie napisać pierwszą część pracy, to tym razem porażką zakończyłaby się druga przygotowana część, czyli podstawy fenomenologicznej destrukcji dziejów ontologii, których motyw przewodni stanowi problematyka temporalności. Zakończenie Bycia $i$ czasu analizami filozofii Kanta, Descartesa i Arystotelesa byłoby po prostu ślepą uliczką, ponieważ przede wszystkim uniemożliwia to, z wielu istotnych powodów, urzeczywistnienie tego, by kwestia bycia pozostała żywa, tj. filozoficznego przemyślenia bycia bez bytu. Heidegger stopniowo doszedł do wniosku, że jeżeli ma znacząco wkroczyć na droge poszukiwania odpowiedzi na pytanie o bycie, to wymienionych wyżej filozofów muszą zastąpić inni. Tymi innymi w rzeczywistości okazali się: Hegel, Leibniz oraz Heraklit i Parmenides.

Niekonsekwencja Heideggera, polegająca na tym, iż zbyt wiele czasu stracił na możliwym urzeczywistnieniu pierwszej opublikowanej koncepcji w Byciu i czasie, kontynuowanej w pracy Kant a problem metafizyki (1929), prowadzi w końcu do zaskakującego paradoksu. Wyrażony został on w takiej formie: „Byt znamy - ale bycie? Czy próba określenia bycia - czy choćby uchwycenie go - nie przyprawia nas o zawrót głowy? Czy bycie nie jest czymś w rodzaju nicości? Rzeczywiście, tak właśnie powiada sam Hegel: »Czyste bycie i czysta nicość są tym samym «" 4 .

Heidegger wyraźnie dostrzega konsekwencje tego faktu w tym, że radykalniej niż dla kogokolwiek przedtem, filozofia stała się dla Hegla logiczną metafizyką. Dlatego musimy stwierdzić, że Heideggerowskie dzieło Kant a problem metafizyki nie mogło skończyć się inaczej, niż tylko filozoficznym peanem na cześć Hegla. To, co powiodło się w 1929 roku, powtórzy się trzydzieści lat później w artykule Kanta teza o byciu (1962), zakończonym w podobny sposób. Kantowska teza o byciu została opracowana przez Heideggera w kontekście rozumienia bycia jako absolutnego pojęcia. Zatem wszystko to, co jest istotne w filozofii Kanta i tak w rezultacie kieruje nas w stronę Hegla. Oczywiście, nie są to wszystkie perspektywy, z jakich można efektywnie patrzeć na filozofię Kanta w XX wieku. Wśród innych

3 Por. M. Heidegger, Bycie i czas, tłum. B. Baran, Warszawa 2008, s. 50.

4 M. Heidegger, Kant a problem metafizyki, tłum. B. Baran, Warszawa 1989, s. 252. 
z pewnością wyróżnia się interpretacja neokantowska ${ }^{5}$, filozofia analityczna także nie jest zupełnie bez znaczenia. Zdaniem Eugena Andreanského, w ramach filozofii analitycznej wpływ ten widoczny jest nie ,tylko w czysto historyczno-filozoficznych rekonstrukcjach, ale także podczas tworzenia własnych koncepcji (...)" 6 .

Günter Figal, jeden z najważniejszych obecnie badaczy filozofii Heideggera, w swej pracy Wstęp do Heideggera słusznie zauważa, iż ten, kto „chce rozumieć sposób filozofowania Heideggera, musi poddać się eksperymentalnemu charakterowi jego dzieła. Dostęp do niego znajdziemy przede wszystkim w miejscach przełomów i zwrotów. W tych miejscach widać, z jaką konsekwencją Heidegger realizuje swój problem oraz jak jest przygotowany, by w przypadku niepowodzenia, natychmiast sformułować go inaczej" ". Można się zgodzić z tą tezą bez zastrzeżeń. To samo zresztą dotyczy następnego twierdzenia Figala: „Kto chce zrozumieć filozofię Heideggera, nie może zadowolić się tym, by zrozumieć tylko samego Heideggera. Do swych licznych i często przy tym najważniejszych myśli doszedł Heidegger zwracając się ku innym filozofom, rozwijając ich poprzez interpretacje tekstów. Dla filozofii Heideggera charakterystyczne jest właśnie to, że stworzył on swą własną, nadzwyczaj oryginalną metodę interpretacji tekstów. Wprowadzenie do Heideggera nie jest zatem możliwe bez tego, abyśmy również nie mówili o Heglu, Husserlu i Diltheyu, Arystotelesie i Platonie, Hölderlinie i Nietzschem, czy Ernstcie Jüngerze" 8.

Nie ze wszystkim jednak w interpretacji Figala możemy się zgodzić. Figal stwierdza: „Przy tym najważniejszymi są Arystoteles i Platon. Wszelka próba zrozumienia Heideggera niezależnie od klasycznej filozofii greckiej będzie skazana na porażkę" 9. Niestety, tezy tej nie można utrzymać. Prawdą jest, że znaczenie filozofii Platona i Arystotelesa dla filozofii Heideggera na początku lat trzydziestych dwudziestego wieku jest ogromne, z czasem jednak wyraźnie maleje. Po zwrocie stopniowo najważniejszymi z greckich filozofów stają się bez wątpienia Heraklit i Parmenides. Dlatego musimy skorygować ocenę Figala, i powiedzieć, że wszelka próba zrozumienia filozofii Heideggera niezależnie od filozofii przedsokratejskiej (Anaksymander, Heraklit i Parmenides) pozostanie bezskuteczna. Jednak Heraklit oraz Parmenides nie stali się przedmiotem jego zainteresowania, mówiąc

\footnotetext{
5 Por. A. J. Noras, Kant a neokantyzm badeński i marburski, Katowice 2005.

6 E. Andreanský, Obraz Kanta $v$ analytickej filozofii, w: Kantov odkaz v kontexte filozofickej prítomnosti, ed. L. Belás, Prešov 2005, s. 111; por. także E. Andreanský, Premeny transcendentalizmu $v$ analytickej filozofi, Prešov 2008, s, 80-91; E. Andreanský, Kant v dimenziách filozofie mysle, w: Človek - dejiny - kultúra III, eds. L. Belás, E. Andreanský, Prešov 2009, s, 61-73.

7 G. Figal, Úvod do Heideggera..., wyd. cyt., s. 9.

8 Tamże.

9 Tamże.
} 
metaforycznie, sami w sobie i dla siebie. Po to, by można było w pełni ukazać ich filozoficzne znaczenie, należy skonfrontować ich myślenie z filozofią Hegla.

Do czego jest zatem konieczna taka historyczno-filozoficzna konfrontacja Heideggera z Heglem? Przede wszystkim do wyeksponowania dwóch kluczowych problemów: 1) filozofii dziejów filozofii; 2) zrozumienia, że sens filozofii nie może być osiągnięty bez odpowiedzi na pytanie: czym jest bycie. Bardzo dobrze rozumie to Figal, kiedy pisze, że ,już Filozofia dziejów Hegla pokazuje, jak można udostępnić tradycyjne teksty w taki sposób, iż interpretuje się je w kategoriach współczesnej terminologii i ujęcia problemowego: Heglowskie rozumienie staje się dla Heideggera wiążące" ${ }^{10}$. Pozostaje się z tym jedynie zgodzić, ale powstaje problem ze zrozumieniem, a następnie także z ukazaniem tego, co zbliża Heideggera do Hegla. Za najważniejsze należy uznać wyznaczenie, a następnie treściowe wypełnienie filozofii dziejów filozofii, która stanowi najważniejszy motyw osiągnięcia znaczącej drogi poznania zarówno dla Heglowskiej, jak i Heideggerowskiej wypowiedzi ontologicznej $^{11}$.

Istotę filozofii dziejów filozofii najwyraźniej jak dotychczas przedstawił w 1942 roku Jan Patočka12. Filozofia dziejów filozofii stanowi wyjątkowy metateoretyczny ruch historyczno-filozoficznego myślenia, którego sensem nigdy nie jest zewnętrzno-empiryczna historyczno-filozoficzna analiza, ale odnalezienie wewnętrznej jedności dziejów filozofii z najważniejszymi logiczno-ontologicznych problemami. Wyznacza ona wspólną filozoficzną platformę dla Hegla i Heideggera. Jeżeli tego nie dostrzeżemy, to stracimy decydującą możliwość zrozumienie ich wzajemnego, nie podlegającego wątpliwości, myślowego związku.

Zapewne najzwięźlej swoje teoretyczne stanowisko filozofii dziejów filozofii przedstawił Hegel w $§ 86$ Małej logiki: „(...) zasadnicza treść dziejów filozofii nie odnosi się do czegoś przeszłego, lecz jest wieczna i istotnie obecna, a wynik tych dziejów nie przedstawia galerii błędów ludzkiego ducha, lecz raczej panteon bogów. Tymi bogami są jednak różne stopnie idei, wynurzające się po sobie w dialektycznym procesie rozwoju (...) początek logiki zbiega się zatem z początkiem właściwych dziejów filozofii. Ów początek znajdujemy w filozofii eleackiej, a konkretnie u Parmenidesa, który rozumie absolut jako byt, mówiąc: istnieje tylko byt, niebyt nie może istnieć. Należy uznać to za właściwy początek filozofii, ponieważ

\footnotetext{
10 Tamże, s. 12.
}

11 Por. M. Heidegger, Czas i bycie, w: M. Heidegger, Ku rzeczy myślenia, tłum. J. Mizera, Warszawa 1999, s. 5-35; por. M. Ješič, Husserlova transcendentálna fenomenológia a Descartes I, „Filozofia”, r. 61, 2006, č. 385-401, s. 9-99, 158-197; M. Ješič, Husserlova transcendentálna fenomenológia a Descartes II, „Filozofia”, r. 61, 2006, č. 6, s. 453-463.

12 Por. J. Patočka, Dějepis filosofie a její jednota, „Česká mysl”, 36, 1942, č. 2, s. 61; por. także V. Leško, Filozofia dejín filozofie, Prešov 2004. s. 254 n. 
filozofia jest w ogóle myślącym poznawaniem i tu po raz pierwszy czyste myślenie - uprzedmiotowiając się - uchwyciło samo siebie" ${ }^{13}$.

Główny rdzeń swej filozofii dziejów filozofii Heidegger bodaj najspójniej przedstawił już w 1922 roku w takiej oto postaci: „Dzieje filozofii są (...) dla badań filozoficznych przedmiotem możliwym do przyjęcia wtedy i tylko wtedy, gdy nie poddają się różnorodnym efektownym przejawom, ale temu, co jest w swej radykalnej jasności godne myślenia, a nauka tak rozumiejąca teraźniejszość nigdy nie wzbogaca wiedzy, lecz idzie dokładnie w przeciwnym kierunku, do niej samej, w celu spotęgowania jej problematyczności (...). W drodze powrotnej od Arystotelesa do jego poprzedników można będzie także rozważyć Parmenidesa teorię o byciu oraz zrozumieć ją jako decydujący krok, który wyznaczył sens i los zachodniej ontologii i logiki" 14 . Uświadomienie sensu zachodniej ontologii i logiki stanowi wspólny filozoficzny cel tak Hegla, jak i Heideggera. Ale każdy z nich realizował to na swój niepowtarzalny sposób.

Dopóki jakikolwiek badacz dzieła Heideggera nie dostrzeże (a to się niestety przydarzyło Figalowi) owej wspólnej filozoficznej przestrzeni wyznaczającej początek zachodniej ontologii i logiki, dopóty nie można ani zrozumieć, ani ukazać tego, co Heidegger miał na myśli, kiedy mówił o Heglu, iż był on ostatnim wielkim Grekiem. W najbardziej przekonywujący sposób dowód owego doniosłego filozoficznego powinowactwa (bliskości) Hegla z filozofią antyczną przedstawił Heidegger w swym wykładzie Hegel a Grecy (1958).

Filozofia dziejów filozofii Hegla jest zdominowana przez kategorię rozwoju i zasadę historycyzmu, bez których autor nie mógłby w ogóle przedstawić swej teorii. Heidegger uważał inaczej. Najcelniej przedstawił to w swych wykładach z semestru zimowego 1927/1928 roku, które opublikowane zostały pod tytułem Fenomenologiczna interpretacja „Krytyki czystego rozumu” Kanta: „Rozwój filozofii nie ma charakteru postępu, ale stara się rozwijać i wyjaśniać stale kilka tych samych problemów, jest niezależną, wolną i zasadniczą walką ludzkiej egzystencji z ciemnością, która w niej stale dochodzi do głosu. A każde wyjaśnienie odkrywa tylko nowe przepaści. Milczenie i upadek filozofii nie oznacza zatem końca postępu, lecz zapomnienie centrum. Dlatego wszelkie filozoficzne odrodzenie jest przebudzeniem się podczas powrotu do tego samego miejsca" ${ }^{15}$.

Dziesięć lat później, w wykładzie Europa i filozofia niemiecka Heidegger ponownie przypomina, że: „Do istoty filozofii należy, że o tym samym mówi stale

13 G. W. F. Hegel, Logika, prel. T. Münz, Bratislava 1961, s. 115.

14 M. Heidegger, Rozvrh fenomenologické interpretace Aristotela, prel. I. Chvatík, Praha 2008, s. 12, 33; por. także H.-G. Gadamer, Heideggerưv „teologický spis” z mládí, w: M. Heidegger, Rozvrh fenomenologické interpetace Aristotela, wyd. cyt., s. 64-71.

15 M. Heidegger, Fenomenologická interpretace Kantovy „Kritiky čistého rozumu”, prel. J. Kuneš, Praha 2004, s. 13-14. 
to samo. A najważniejszymi, wyróżniającymi się myślicielami są ci, którym się to udało. Oznacza to, że: właściwe dzieje filozofii są dziejami tylko kilku prostych pytań. Rzekome dowolne bogactwo stanowisk oraz wymienność systemów jest zatem w zasadzie tylko i wyłącznie tym samym jednym jedynym, tak jak jest tego zdolny doświadczyć dokładnie ten a nie inny myśliciel" 16.

Zrozumienie początków filozofii greckiej, a tym samym filozofii zachodniej w ogóle, jest w decydujący sposób dla Heideggera połączone z właściwym rozumieniem słów, jakimi Grecy określali bycie i prawdę. We wczesnej filozofii greckiej podstawowym słowem dla oznaczanie bycia było $\varphi v ́ \sigma \iota \varsigma$. Tutaj jednak powstaje pierwszy poważny błąd w rozumieniu wczesnej filozofii greckiej, jeżeli wprost pojmujemy ją jako filozofię przyrody. Jak dowodzi Heidegger pogląd ten jest nieporozumieniem. Powód jest oczywisty. „Фv́ $\sigma \iota \varsigma$ oznacza: wykiełkowanie - na przykład wykiełkowanie róży - w znaczeniu wychodzenia na jaw, wschodzenie, wydawania się; wydawać się - tak jak mówimy: książka została wydana, jest tu. W $\varphi v ́ \sigma \iota \varsigma$ pobrzmiewa Grekom nazwa dla bycia: prezentuje się i równocześnie pozostaje nieruchome. Dopiero w byciu, tj. w tym, co tu pozostaje nieruchome i spoczywa samo w sobie, w greckich rzeźbach i greckich świątyniach, życie tego narodu osiąga bycie, jasne i poważne trwanie; owe rzeźby i świątynie nie są ani imitacją, ani wyrazem czegoś, ale ustanowionymi mocami i prawami greckiego bycia" 17 .

Rozpoznając dalej problem bycia, Heidegger próbuje obalić jedną z najbardziej błędnych interpretacji wczesnej filozofii greckiej, która uwidacznia sprzeczność filozoficznych teorii Heraklita i Parmenidesa. I tak, jeżeli Heraklit rzekomo miał ponad bycie przekładać stawanie, tak Parmenides z kolei nad stawianie wynosił bycie. Tak wyrażony pogląd Heidegger stanowczo odrzuca. Parmenides „mówi wyłącznie o byciu jako o Jednym i Tym samym, ponieważ wie, że bycie jest nieustannie zagrażającym pozorem, który należy do niego jak cień" ${ }^{18}$. Heraklit przeciwnie, mówi o stawianiu „tylko dlatego, by włączyć go do Jednego, do jedno-

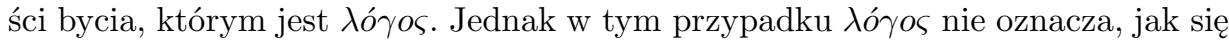
to później tłumaczyło, rozum i mowę, ale zbieranie, pierwotne skupienie wszelkich przeciwieństw do Jednego (...)" 19 .

Heraklit i Parmenides to filozofowie, którzy - jak zauważa Heidegger - poszukują tego samego, lecz z przeciwnych stron, ponieważ myślą oni o bycie nie w kontekście pozoru i stawiania, ale równocześnie z niezmienności. „Przy takim początku nie było można jednak pozostać; ponieważ początek ten nie jest

16 M. Heidegger, Evropa a německá filosofie, prel I. Šnebergová, J. Šindelář, „Filosofický časopis", r. 44, 1996, č. 1, s. 77.

17 Tamże, s. 79.

18 Tamże, s. 80

19 Tamże. 
- jak zamierzam wyjaśnić później, zawładnięty rozwojem - czymś niedoskonałym i mało znaczącym, ale jest tym, co największe w całości swojej treści" ${ }^{20}$. W tym jednoznacznie została wyrażona zasadnicza różnica między Heglowskim i Heideggerowskim rozumieniem dziejów filozofii. Podczas gdy dla Hegla rozumienie dziejów filozoficznego myślenia nie jest możliwe bez kategorii rozwoju, dla Heideggera takie założenie absolutnie jest nie do przyjęcia.

Tym, o czym będzie starał się nas przekonać autor Bycia i czasu, nieprzerwanie aż do końca swej kariery, to przeświadczenie, że najtrudniejsze w filozofii jest zachowanie początku. W ten sposób chciał wyrazić fakt, że ,zasadnicze określenie bycie i prawdy przeszło przemianę, która wprawdzie zakłada początek, ale już go nie przezwycięża" ${ }^{21}$. Zerwanie z początkiem Heidegger jednoznacznie wiąże z Platonem i Arystotelesem. W 1936 roku jest Heidegger niezłomnie przekonany - później tę ocenę zmieni - że na Logice Hegla „kończy się droga filozofii zachodniej od Platona i Arystotelesa, ale nie droga od jej początku. Ten tu nie polega na tym, aby został przezwyciężony a dzięki spojrzeniu wstecz stał się wyłącznie osiągalny ze stanowiska, które się od niego odwróciło, to znaczy, którego go nie doświadczyło" 22.

W trzech obszernych seriach wykładów poświęconych kolejno Anaksymandrowi i Parmenidesowi (1923) ${ }^{23}$, Parmenidesowi (1942) ${ }^{24}$ oraz Heraklitowi (1944) ${ }^{25}$ podjął Heidegger ogromny wysiłek, by zmierzyć się z interpretacją początków zachodniej filozofii. Naczelną strategią wspomnianych wyżej wykładów była próba zbadania rozległej przestrzeni początków zachodniego myślenia, kładąc nacisk na problem prawdy bycia oraz celu myślenia metafizycznego ${ }^{26}$. Stanowią one pomost do tego, co zostało później w wykładzie Co to jest filozofia? z 1955 roku wypowiedziane wprawdzie krótko, ale zdecydowanie: „Heraklit i Parmenides nie byli jeszcze »filozofami«. Dlaczego? Ponieważ byli »bardziej « myślicielami” 27. Słowa „bardziej” nie użył w tym przypadku Heidegger po to, by ocenić filozoficzny rezultat, ale po to, by ukazać drogę do innego wymiar myślenia. „Heraklit i Parmenides byli większymi myślicielami w tym sensie, że pozostawali jeszcze w zgodności

\footnotetext{
20 Tamże.

21 Tamże, s. 81.

22 Tamże, s. 82.

23 Por. M. Heidegger, Der Anfang der abendländischen Philosophie (Anaximander und Parmenides), GA Bd. 35, Frankfurt am Main 1998.

24 Por. M. Heidegger, Parmenides, GA Bd. 54, Frankfurt am Main 1992.

25 Por. M. Heidegger, Herakleitos, GA 55, Frankfurt am Main 1994.

26 Por. tamże, s. 378 i n.; por. także M. Heidegger, Przyczynki do filozofii. (Z wydarzenia), tłum. B. Baran, J. Mizera, Kraków 1996.

27 M. Heidegger, Co to jest filozofia, tłum. S. Blandzi, w: Heidegger dzisiaj, P. Marciszuk, C. Wodziński (red.), Alehteia 1 (4), Warszawa 1990, s. 39.
} 


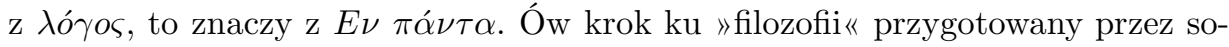
fistykę, dokonany został przede wszystkim przez Sokratesa i Platona" 28. Skąd jednak Heidegger wie o tym, iż Heraklit i Parmenides pozostawali jeszcze w zgodności z $\lambda o ́ \gamma o \varsigma$, zostanie z kolei dla czytelnika tajemnicą. Ale to przynależy zapewne do jednej z owych nie przemyślanych strategicznych właściwości Heideggerowskiej twórczości po zwrocie.

W 1949 roku we Wprowadzeniu do artykułu Czym jest metafizyka? wyraźnie pisze, że pytanie o sens bycia, zawarte po raz pierwszy w pracy Bycie $i$ czas, przekształca się teraz w kwestie prawdy bycia. Pociąga to za sobą bardzo poważne konsekwencje. Idzie bowiem teraz o drogę od metafizyki, jako refleksji nad bytującym bytem, do myślenia o prawdzie bycia. Innymi słowy, główne pytanie metafizyczne zostaje przekształcone z początkowego pytania Leibniza („dlaczego istnieje raczej coś niż nic?) do postaci: „dlaczego w ogóle jest byt, nie zaś raczej Nic?" ${ }^{29}$ Heidegger zatem słusznie zapytuje: co jest teraz bardziej zagadkowe: byt czy bycie? Odpowiedź na pierwszy rzut oka jest łatwa. Niewątpliwie to bycie jest bardziej zagadkowe. Problem powstaje jednak podczas ponownego uświadomienia sobie nierozerwalności bytu i bycia.

W Postowiu do artykułu Czym jest metafizyka (1943) zdecydowanie ostrzega, że bycie nie jest bytującą jakością tego, co jest. „Bycia nie można na wzór bytu przedmiotowo przedstawić i dostawić" ${ }^{30}$. Tak oto dotarliśmy już do epicentrum Heideggerowskiego zapytywania o bycie oraz byt, które skrywa się za poszukiwaniem odpowiedzi na pytanie: czy istnieje lub nie istnieje bycie bez bytu? Problem różnicy ontologicznej czeka zatem na swoje ostateczne rozwiązanie. W czwartym wydaniu Posłowia (1943) Heidegger zmienia zdanie zwarte w poprzednich wydaniach tekstu Czym jest metafizyka? („(...) bycie nigdy nie istniej bez bytu i (...) byt nigdy nie jest bez bycia”) do takiej oto postaci: „(...) skoro tylko przynależy do prawdy bycia, że nie istoczy się ona nigdy bez bytu i że nigdy też nie ma bytu, bez bycia" ${ }^{31}$. Teraz należy stanowczo zapytać: istnieje czy nie istnieje bycie bez bytu? Odpowiedź znajdziemy dopiero w wykładzie Heideggera Czas i bycie (1962).

Między rokiem 1943 a wykładem Czas $i$ bycie wydarzyło się jednak wiele, o czym należy wspomnieć. To, co jest najważniejsze ma związek z wykładem Heideggera Hegel a Grecy. W nim badany problem dziejów filozofii osiąga swą najwyższą postać, która do końca jego twórczości nie została już przezwyciężona.

\footnotetext{
28 Tamże, s. 39.

29 M. Heidegger, „Czym jest metafizyka?” Wprowadzenie, tłum. K. Wolicki, w: M. Heidegger, Znaki drogi, tłum. S. Blandzi i inni, Warszawa 1999, s. 327; por. M. Ješič, Heidegger, Descartes a metafyzika subjektivity, „Filozofia”, r. 65, 2010, č. 2, s. 136.

30 M. Heidegger, „Czym jest metafizyka?” Postowie, tłum. K. Wolicki, w: M. Heidegger, Znaki drogi..., wyd. cyt., s. 265.

31 Tamże, s. 266.
} 
Jest to znakomita próba rozliczenia się z Heglem a jednocześnie rozwiązania wyżej wspomnianego problem. Już pierwsze słowa Heideggera są znaczące. Chce on bowiem zajmować się Heglem z perspektywy współczesnego stanowiska. W żadnym przypadku nie możemy zatem oczekiwać podejścia historyczno-filozoficznego, ale tylko i wyłączenie filozoficzno-problemowe. Chodzi mu o wtargnięcie do rzeczy myślenia, abyśmy mogli postawić pytanie a jednocześnie byli przygotowani owe myślenie zmienić, o ile wymaga tego sama rzecz. Czy jednak, by dotrzeć do rzeczy myślenia, nie potrzebujemy w ogóle wielkiej drogi okrężnej przez Hegla i Greków? Odpowiedź Heideggera jest jednoznaczna. Potrzebujemy owej drogi, która w swojej istocie nie jest drogą okrężną, ponieważ właściwego doświadczenia duchowej tradycji dostarcza nam nieustannie współczesność, to, co jest stale w grze, już nie w swej dziejowej postaci, lecz jako współczesna rzecz myślenia.

Najwyższą ocenę, jaką mógł dostać filozof, Heidegger wystawia Heglowskiej recepcji filozofii antycznej w horyzoncie współczesności. „....) Hegel po raz pierwszy myśli bowiem filozofię Greków jako całość, a całość tę myśli w sposób filozoficzny" 32 . Hegel nie wyjaśnia dziejów, ale dzieje myśli. Nikt przed nim nie robił w filozofii niczego podobnego. Tym samym otworzyła się w ogóle możliwość powstania filozofii dziejów filozofii, która faktycznie nie byłaby możliwa bez owego istotnego myślenia filozoficznego duchowego dziedzictwa. W filozofii dziejów filozofii chodzi zatem przede wszystkim o rzecz myślenia. Stało się to możliwe także dlatego - jak to dodaje Heidegger - że dzieje filozofii są dla Hegla jednolitym i koniecznym procesem ruchu ducha do samego siebie. Jak dotąd wszystko jest jasne. Problem rozpoczyna się jednak wraz ze zrozumieniem i wyjaśnieniem czterech podstawowych słów filozofii greckiej, które pozostają w fundamentalnym związku z podstawowym pojęciem filozofii w ogóle - byciem.

Jak uważa Heidegger, owe cztery podstawowe słowa filozofii greckiej (hen - Parmenidesa, logos - Heraklita, idea - Platona oraz energeia - Arystotelesa), są przez Hegla źle przetłumaczone, gdyż zostały błędnie zinterpretowane. Hegel przekłada hen Parmenidesa jako wszystko, logos Heraklita jako rozum, Platońską idea jako pojęcie a energeia Arystotelesa jako rzeczywistośc ${ }^{33}$. Główne pojęcie filozofii greckiej zostały przez Hegla błędnie przełożone dlatego, że wyjaśniał je w horyzoncie swej własnej filozofii jako jej wstępny etap. I tak odkryliśmy istotę sprawy. Albowiem Heidegger zarzuca Heglowi dokładnie to samo, co sam czynił z jeszcze większą konsekwencją i jednoznacznością. Doprowadził on bowiem aż do skrajności interpretowanie podstawowych pojęć filozofii greckiej z pozycji swej własnej filozofii.

32 M. Heidegger, Hegel i Grecy, tłum. J. Mizera, w: M. Heidegger, Znaki drogi..., wyd. cyt., s. 364 .

33 Por. tamże, s. 369. 
Rozstrzygającą różnicę między Heglowskim rozumieniem filozofii greckiej a swoim, dostrzega Heidegger w tym, że filozofia nie jest stopniem do prawdy, jak jest o tym jeszcze przeświadczony Hegel, ale - bycia. Hegel nie mógł tego zrozumieć i dlatego nie mógł również dostrzec, że prawda i bycie są w istotny sposób nieodłącznie związane. Po zwrocie bardziej już jako prorok niż filozof, Heidegger oznajmia całej ludzkości, że $A \lambda \eta ́ \theta \varepsilon \iota \alpha$ włada całym europejskim myśleniem, które jest światowym panowaniem. Bycie jest $A \lambda \dot{\eta} \theta \varepsilon \iota \alpha$ i $A \lambda \dot{\eta} \theta \varepsilon \iota \alpha$ jest byciem. Oczywiście, możemy w to uwierzyć, ale nie musimy. A raczej nie musimy niż nie możemy! Dlaczego? Ponieważ poza wszystkim europejskie myślenie owego bycia rządzi się, ściśle mówiąc, bez tego, aby było w swej prawdzie doświadczonalne i w ogóle wyrażalne. Tu dochodzi do rozstrzygającej konfrontacji z Heglem. Najważniejszy przedstawiciel idealizmu niemieckiego myli się przede wszystkim w tym - zdaniem Heideggera - że rozumie rozwój filozofii jako dziejowe dokonywanie się.

Heidegger w Zasadach myślenia (1958) wystąpił przeciw temu tak zdecydowanie, jak w żadnym innym dziele. Pyta on o to, co wydarzyło się w dziejach zachodniego myślenia od czasów Fichtego, Schellinga i Hegla. Urzeczywistniło się mianowicie coś, co wyniosło myślenie do najwyższych wymiarów swych możliwości. Heidegger znakomicie to diagnozuje: „Myślenie staje się świadomie dialektyczne (...). Doskonałe urzeczywistnienie teoretyczno-spekulatywnego rozwinięcia dialektyki do zamkniętej całości zostaje zrealizowane w dziele Hegla, które nosi nazwę: Nauka logiki" 34 .

Ten historyczno-filozoficzny fakt Heidegger wykorzystuje po to, by ukazać, że wprawdzie wyniesienie myślenie do wymiaru dialektyki jest dziejowym przypadkiem, ale tylko dlatego, gdyż jesteśmy zbyt przyzwyczajeni do tego, by przedstawiać sobie dzieje inaczej niż historycznie. Najważniejszym, o ile nie chcemy zejść na manowce, jest uświadomienie sobie relacji, jaka zachodzi między Heideggerem a Heglem. Heidegger chce bowiem doprowadzić nas do przeciwnego stanowiska, niż to, dzięki któremu wciąż uznajemy Hegla za wielkiego filozofa, tj. tezy, że istnienie człowieka i społeczeństwa jest dziejowym samostwarzaniem. Człowiek jest człowiekiem o tyle, o ile jest dziejowym bytem. Dzieje są zatem sferą bycia człowieka a nie dziejów bycia ${ }^{35}$. Zamiast filozofii dziejów Heidegger proponuje dzieje bycia. Dzieje mogą odnosić się do bytu jako jestestwo, które „rozumie samo siebie zawsze na podstawie swej egzystencji, własnej możliwości (...)" 36 . Wszystko inne jest tylko karykaturą dziejów, a być może dzieje bycia są karykaturą największą.

34 M. Heidegger, Básnicky bydlí člověk, prel. I. Chvatík, Praha 1993, s. 165.

35 Por. M. Heidegger, Geschichte des Seyns, GA Bd. 69, Frankfurt am Main 1998, s. 5 n.

36 M. Heidegger, Bycie $i$ czas..., wyd. cyt., s. 17. 
Początek europejskiego myślenia wyznacza według Heideggera zdanie Parme-

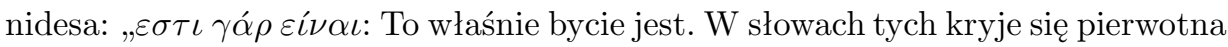
tajemnica dla wszelkiego myślenia" ${ }^{37}$. Oczywiście, o ile uwierzymy tym proroczym słowom. Wątpliwość Heideggera, że zdanie Parmenidesa także w XX wieku pozostaje nieprzemyślane, oznacza zatem tylko jedno. Postęp w dziejach filozofii jest tylko chimerą. Tu musimy zgodzić się z Heideggerem, że ów postęp naprawdę nie nastał, o ile tylko zredukujemy filozofię do poszukiwania odpowiedzi na jedno pytanie - pytanie o bycie. Zatem Parmenides jest początkiem a jednocześnie końcem dziejów metafizyki bycia. Heidegger jednak nie posunął tego myślenia choćby o malutki krok do przodu. Przeciwnie. Przekonywujące, osobiste świadectwo o tym fakcie pozostawił nam Hans Georg Gadamer: „Pod koniec swojego życia Heidegger doszedł aż do tego, że w ogóle już nie używał słowa filozofia, ponieważ zadanie doprowadzenia metafizyki jako formy pojęciowego myślenia (...) do nowego horyzontu przyszłości, wydało mu się niemożliwe do zrealizowania" 38 .

Niemożliwość zbudowania poszukiwanej przez Heideggera metafizyki bycia łączy istnienie z rozumieniem rzeczy myślenia. Wypełnienie jej zawartości jest bezpośrednio uzależnione od ostatecznego przemyślenia różnicy ontologicznej. To proponuje nam Heidegger w wykładzie Czas i bycie (1962), który w zasadzie kończy jego dzieło. Poza tym, by już więcej nie komplikować badanego tematu, odwołam się do Patočki, który już dawno przede mną wysunął kategoryczny wniosek pod adresem jedynej w swoim rodzaju filozoficznej próby, o jaką się w dziejach filozofii pokusił Heidegger, a mianowicie przemyślenia bycia bez bytu ${ }^{39}$. Czeski fenomenolog powiedział jasno: „bycie jest byciem bytu” 40 . W innym miejscu dodaje do tego jeszcze pogląd, że problem bycia, tak jak go sformułował Heidegger, uważa „za problem niedostatecznie przemyślany” ${ }^{41}$. Trzeba się z tą oceną w pełni zgodzić.

W opublikowanym pośmiertnie wywiadzie, udzielonym dla czasopisma „Der Spiegel" (23.09.1966), Heidegger mówił, że cała jego praca, realizowana w wykładach i seminariach ,z minionych 30 lat, wszystko to było w gruncie rzeczy tylko interpretacją filozofii zachodniej" ${ }^{42}$. Gdybym chciał traktować powyższą ocenę wprost, doszedłbym do wniosku, że Heidegger angażował się istotnie w filozofię

37 M. Heidegger, List o „humanizmie”, tłum. J. Tischnr, w: M. Heidegger, Znaki drogi..., wyd. cyt., s. 288.

38 H.-G. Gadamer, Evropa a Oikúmené, „Filosofický časopis”, r. 44, 1996, č. 1, s. 86.

39 Por. M. Heidegger, Czas i bycie..., wyd. cyt., s. 35.

40 J. Patočka, Čtyři semináře k problému Evropy, w: J. Patočka, Péče o duši III, Praha 2002, s. 384 .

41 J. Patočka, Platón a Evropa, w: J. Patočka, Péče o duši II, Praha 1999, s. 310.

42 M. Heidegger, Tylko Bóg miałby nas uratować, tłum. M. Łukasiewicz, w: Heidegger dzisiaj..., wyd. cyt., s. 380 . 
głównie jako historyk filozofii. Nie jest to jednak prawdą. Podczas całej swojej kariery Heidegger nie interesował się problemem interpretacji zachodnio-europejskiej filozofii jako historyk filozofii, ale tylko jako filozof dziejów zachodnio-europejskiej filozofii. Filozofia dziejów filozofii Heideggera stanowi najbardziej reprezentatywny przykład silnego modelu, który jest do dziś filozoficznie nieosiągalny oraz stanowi nieprzemyślaną podstawę jego filozofowania zarówno przed, jak i po zwrocie ${ }^{43}$.

Heidegger programowo zradykalizował myśl Kanta ( „nie ma nic nadzwyczajnego ani w potocznej rozmowie, ani w dziełach porównywalnych myśli, jakie autor wypowiada o swym temacie, rozumiemy go ostatecznie lepiej, niż on sam siebie rozumiał (...)”) do postaci „Właściwie rozumieć Kanta oznacza zatem rozumieć go lepiej, niż on sam siebie rozumiał" 44. Rzeczywiście, Heidegger nie tylko właściwie rozumiał filozofię Kanta, ale także całe dzieje filozofii, a ponieważ był przekonany, że tak rzeczywiście było, mógł je w pełnym zakresie podporządkować jedynej kwestii, która go w filozofii zajmowała - kwestii bycia. Lecz taki sposób podejścia do dziejów filozofii w pewnym sensie zmienia się w najwyższą formę filozoficznej przemocy, która niewątpliwie najlepiej charakteryzuje filozofię Heideggera.

Realizowana przez Heideggera filozoficzna destrukcja odnosząca się do stanowisk metafizycznych w dziejach filozofii skupia się głównie na badaniu drogi powrotnej - od Arystotelesa do Parmenidesa - w celu określenia nauki o byciu Parmenidesa, zrozumienia jej jako decydującego kroku, który wyznaczył sens i los zachodniej ontologii i logiki aż do metafizyki bycia. Zgadzam się z oceną Gadamera, iż Heglowska konstrukcja dziejów filozoficznego myślenia jest teleologiczna konstrukcją od końca, podczas gdy Heideggerowskie rozumienie dziejów jest konstrukcją od początku. W nawiązaniu do drugiej koncepcji należy zauważyć, iż pomimo ogromnej teoretycznej próby przemyślenia bycia bez bytu, w końcu pozostała tylko oryginalnym zwiastunem filozoficznej wizji. Dlatego bez zastrzeżeń możemy zgodzić się z własną oceną Heideggera, że Bycie i czas było porażką. Ale to samo można powiedzieć o jego metafizyce bycia. Artykuł Czas $i$ bycie ostatecznie potwierdza niepowodzenie Heideggera. Uznanie tego historyczno-filozoficznego faktu oznacza zarazem wyzbycie się nieuzasadnionego uwielbienia dla Heideggera jako najważniejszego filozofa XX wieku.

\section{Z języka słowackiego przełożył Dariusz Bęben}

\footnotetext{
43 Por. tamże, s. 383; por. także F. Novosád, Pozvanie k Heideggerovi, Bratislava 1995, s. 9 n.

44 M. Heidegger, Fenomenologická interpretace Kantovy „Kritiky čistého rozumu”, wyd. cyt., s. $14-15$
} 